\title{
Preliminary screening of pesticides used by farmers in North West Cameroon
}

\author{
Charlie C. Nguemo ${ }^{a}$, Margaret Tita ${ }^{a}$, Mosaad A. Abdel-Wahhab ${ }^{b, 1, *}$ \\ ${ }^{a}$ Department of Biology, Higher Teachers Training College Bambili, University of Bamenda, Cameroon. \\ ${ }^{b}$ Food Toxicology \& Contaminants Department, National Research Center, Dokki, Cairo, Egypt \\ ${ }^{1}$ mosaad_abdelwahhab@yahoo.com (MAA), Tel.: +2 2283 1943; fax: +2 33370931 \\ * corresponding author
}

ARTICLE INFO

Article history

Received June 05, 2019

Revised August 31, 2019

Accepted November 02, 2019

Keywords:

pesticides

crops

farmers

Tubah Sub-Division

Cameroon

\section{ABSTRACT}

This study aimed to evaluate pesticide use in farmers in Tubah, North West of Cameroon. The data collected would be valuable for pesticide policies to reduce the effects of pesticides on human health and the environment. This survey was carried out in November and December 2016 in Tubah Sub-Division, located in Mezam Division region of North West Cameroon. A survey was conducted on 120 homesteads of the area of the study. The results revealed that $80 \%$ of farmers were female. 59.2\% had completed primary education whereas no tertiary education was reported among respondents. Insects were the major pests (67.5\%) followed by fungi $(19.2 \%)$, and finally rodents $(11.7 \%)$. The commonly used pesticides were insecticides; however, herbicides were also used before planting. 19.2\% of the farmers fed their livestock and poultry pesticide-treated crops. This study found that farmers in Bambili lacked knowledge in safe handling and use of pesticides. Training programs should be applied to minimize the adverse hazards of pesticides on human health and the environment.

This is an open access article under the CC-BY-SA license.

\section{Introduction}

Intense agricultural production using pesticides has become a prominent feature of the modern agricultural scene (Tilman et al., 2002). Nevertheless, dependence on pesticides for farming may pose unintended long- term hazardous effects on human health as well as the environment (Pimentel, 2005). Exposure to pesticides is a prevalent problem in developing countries. Prolonged exposure is associated with adverse impacts on health including birth defects and cancer resulting in morbidity (FAO, 2014; Litchfield, 2005). These adverse effects on health and the environment are a direct result of the misuse and/or the overuse of pesticides. Examples of pesticide misuse include deviating from recommended dosages and methods of application (Dasgupta et al., 2007), using illegal or expired pesticides (Hajjar, 2012; Verger and Boobis, 2013) as well as improper handling, storage, and disposal of pesticide residues (Stadlinger et al., 2011; Damalas et al., 2006).

Previous studies have stressed the importance of pesticide safety knowledge and education. It can be argued that knowledge and education does not completely prevent exposure to risk of pesticides as exposure cannot be controlled by farmers and forms an importantefarm environment (Ciesielski et al., 1994). Moreover, it can be argued that the effectiveness of policies to protect the environment especially in developing countries is doubtful, as economic constraints pressures workers into making choices that invariably maximize profits. Economic instability and poverty pressure farmers to continue to work in conditions that most likely will continue to increase their 
exposure to risk and hazards (House et al., 1990; Williams, 1990). Such conditions sometimes are associated with individual and group processes that directly affect risk behavior or health. Nevertheless, worker education programs on safety and work practice are needed as key components in drafting regulations for the protection of workers from pesticide risk and hazards (Stenzel, 1991). Several reports show that excessive use of pesticides in developing countries is connected to the lack of education and training, poor availability of pesticides, lack of information on the hazards of pesticide use and unwillingness of farmers to accept risk of crop loss (Hashemi and Damalas, 2011; Khan et al., 2015; Wilson and Tisdell, 2001).

Tubah Sub-Division of Mezam Division located at North West Cameroon is one such agricultural area where pesticides are heavily used on crops including maize, tomatoes, cabbages and coffee. Numerous health problems have been reported in this community which point to the indiscriminate usage of pesticides. In general, farmers were unaware of the health risks of pesticide use to themselves and the consumer. Therefore, the main objective of the current study was to evaluate pesticide use on crops by farmers in Tubah Sub-Division.

\section{Materials and methods}

\subsection{Description of study area}

This study was carried out in November 2016 in Tubah Sub-Division, Mezam Division, North West Cameroon (Fig. 1). The study area is located at latitude $5^{\circ} 99^{\prime} 0^{\prime}$ north and longitude $10^{\circ}$ $15^{\prime} 00^{\prime}$ east at an altitude of $900 \mathrm{~m}$ above sea level. It has a humid and tropical climate and annual rainfall of about $2200 \mathrm{~mm}$. The average temperature is about $20.67{ }^{\circ} \mathrm{C}$ (Focho et al., 2009).

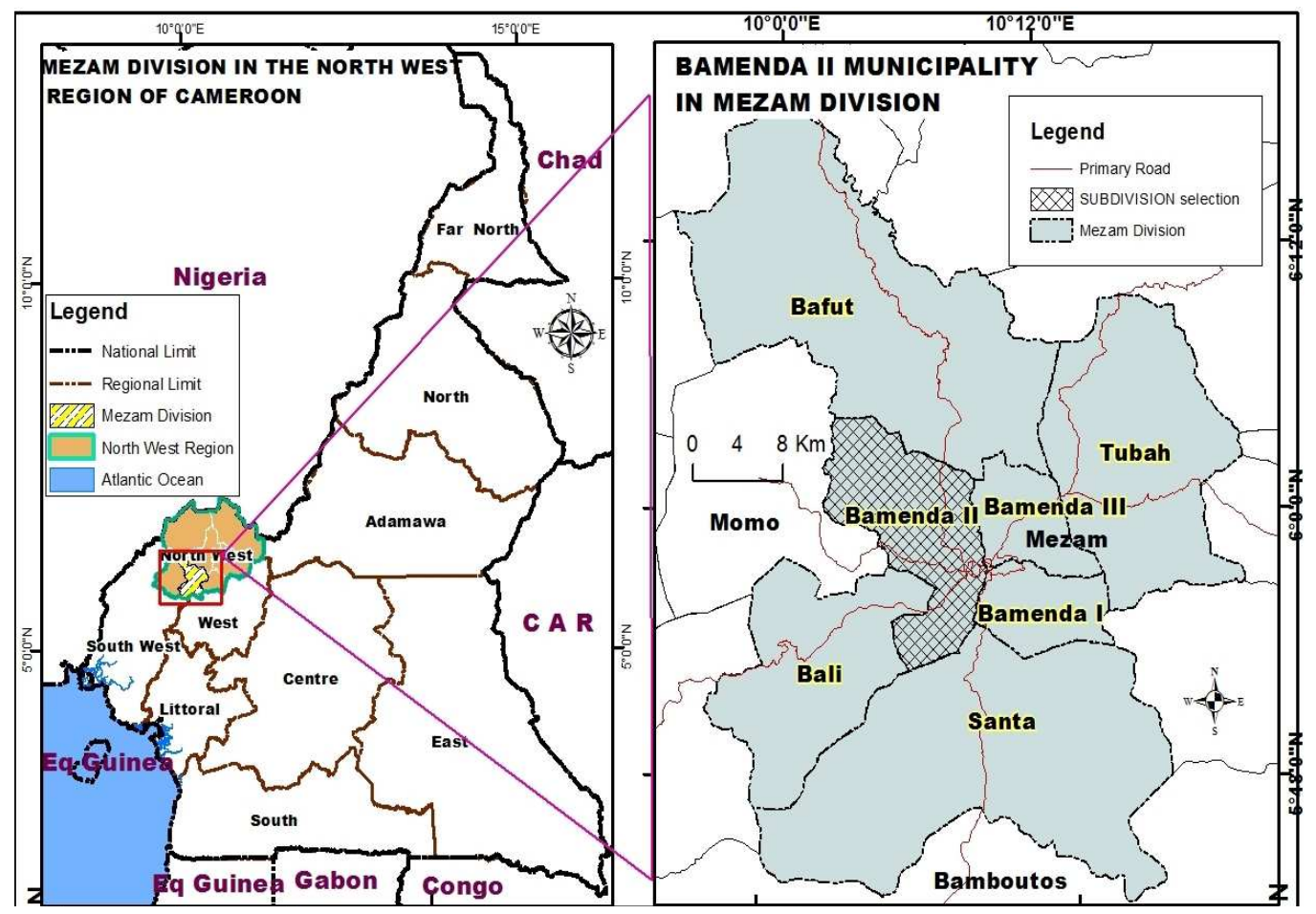

Fig. 1 Map showing the location of the study area at Tubah sub-division

\subsection{Questionnaire development and delivery}

This survey was conducted via questionnaire. The questionnaire was prepared according to the standard format set by Mugenda and Mugenda (1999) and Gay (1992) and administered to 120 randomly sampled homesteads of the study area. The response to each item in the questionnaire was tabulated and its scientific relevance discussed. 


\subsection{Method}

\subsubsection{Questionnaire Administration}

This study was carried out between November and December 2016 through diagnostic surveys, formal interviews and field observations. Information on the pesticides used, target crops, type of pests and common management practice was collected to establish detailed understanding of the factors contributing to pesticide use in Tubah Sub-Division. The survey focused on major pesticide-intensive crops such as vegetables, maize, beans, tubers and groundnuts. Face-to-face interviews were conducted with 120 farmers. The study purpose and importance of the interview was explained to farmers upon visiting their homes. A questionnaire was handed to be filled out by the family head with clarification from the research assistant where necessary. For illiterate family heads, a research assistant assisted in the filling of the questionnaire and pesticides were catogrized according to their function to insecticides, herbicides and nematicides.

\subsection{Data analysis}

The data was analyzed and tabulated for total values and percentages for categorical data. Frequencies and percentages were summarized in and presented in the results section.

\section{Results}

Out of the 120 farmers who responded to the survey, $80 \%$ of the respondents were females and $20 \%$ were males. Most farmers completed only their primary education $(59.2 \%)$, while $40.8 \%$ completed secondary education. None of the respondents received formal tertiary education. Most of the families $(50.8 \%)$ consisted of 4-7 members, $43.4 \%$ consisted of 8-12 members and only $5.8 \%$ of the families consisted of $1-3$ members. $60.8 \%$ of the families owned small farms (0-5 ha), $39.2 \%$ owned medium farms (5-10 ha) while $25.8 \%$ of them owned farms of 15 ha or more. The current survey also showed that $60.8 \%$ of the families had been farming for more than 10 years and $25.8 \%$ farmed for less than 10 years.

The majority of respondents $(90 \%)$ were able to identify different pests infecting their crops. Insects were reported as the most important pest (67.5\%), followed by fungi $(19.2 \%)$ and finally rodents $(11.7 \%)$. Nematode infection was almost negligible, affecting only $1.6 \%$ of the farmers (Fig.2).

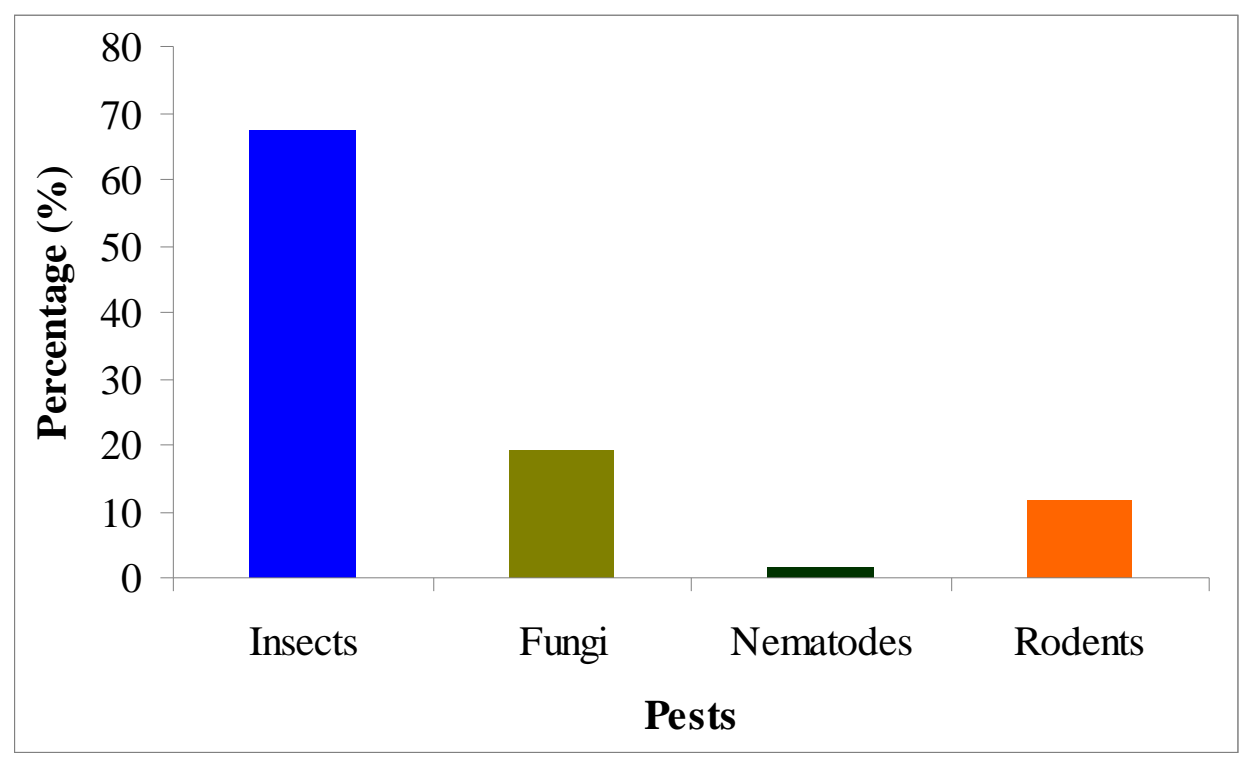

Fig. 2 Pests attacking crops in Bambili, Cameroon 
The current results show that farmers in Bambili opt to use insecticides mainly for control of pests in vegetable crops $(92.2 \%), 50 \%$ for control of pests in maize crops, $70 \%$ for pest control in bean and tuber crops, and $27.5 \%$ for pest control in groundnut crops (Table 1). None of the farmers used nematicides for pest control in target crops except maize, where $10 \%$ of these farmers used nematicide for pest control. $32 \%$ of farmers used fungicides for pest control in maize, while $25.8 \%$ and $10.8 \%$ of farmers used fungicides for pest control in beans and tubers, respectively. Fungicide was not applied for pest control in vegetables and groundnuts. About $61.7 \%$ and $10 \%$ of these farmers used rodenticides for groundnut and tubers, respectively; however, use of rodenticide was not reported for pest control in vegetable, maize and beans. Herbicides were applied for groundnut, tubers, vegetables, maize and bean crops by 10.8, 9.2, 7.5, 7 and $4.2 \%$ of farmers, respectively (Fig. 3). It is of interest to mention that herbicide was applied before planting to minimize competition between weeds and crops; however, in some sports, herbicides were applied after planting. The current results also show that $19.2 \%$ of respondents reported that they fed their livestock and poultry pesticide-treated crops. Pesticide use was used mainly in weed control $(80.8 \%)$, while malaria vector control and cash crop (coffee) spraying were not reported in the area of study (Table 2).

Table 1 Frequency of different types of pesticides used and target crops

\begin{tabular}{|c|c|c|c|}
\hline Target crops & Types of pesticides & $\begin{array}{c}\text { Number of respondents } \\
\text { (frequency) }\end{array}$ & Percentage (\%) \\
\hline \multirow[t]{5}{*}{ Vegetable } & Insecticide & 111 & 92.2 \\
\hline & Nematicide & Nil & Nil \\
\hline & Fungicide & Nil & Nil \\
\hline & Rodenticide & Nil & Nil \\
\hline & Herbicide & 09 & 07.5 \\
\hline \multirow[t]{5}{*}{ Maize } & Insecticide & 60 & 50 \\
\hline & Nematicide & 12 & 10 \\
\hline & Fungicide & 40 & 33 \\
\hline & Rodenticide & Nil & Nil \\
\hline & Herbicide & 08 & 07 \\
\hline \multirow[t]{5}{*}{ Beans } & Insecticide & 84 & 70 \\
\hline & Nematicide & Nil & Nil \\
\hline & Fungicide & 31 & 25.8 \\
\hline & Rodenticide & Nil & Nil \\
\hline & Herbicide & 05 & 04.2 \\
\hline \multirow[t]{5}{*}{ Tubers } & Insecticide & 84 & 70 \\
\hline & Nematicide & Nil & Nil \\
\hline & Fungicide & 13 & 10.8 \\
\hline & Rodenticide & 12 & 10 \\
\hline & Herbicide & 11 & 09.2 \\
\hline \multirow[t]{5}{*}{ Groundnut } & Insecticide & 33 & 27.5 \\
\hline & Nematicide & Nil & Nil \\
\hline & Fungicide & Nil & Nil \\
\hline & Rodenticide & 74 & 61.7 \\
\hline & Herbicide & 13 & 10.8 \\
\hline
\end{tabular}




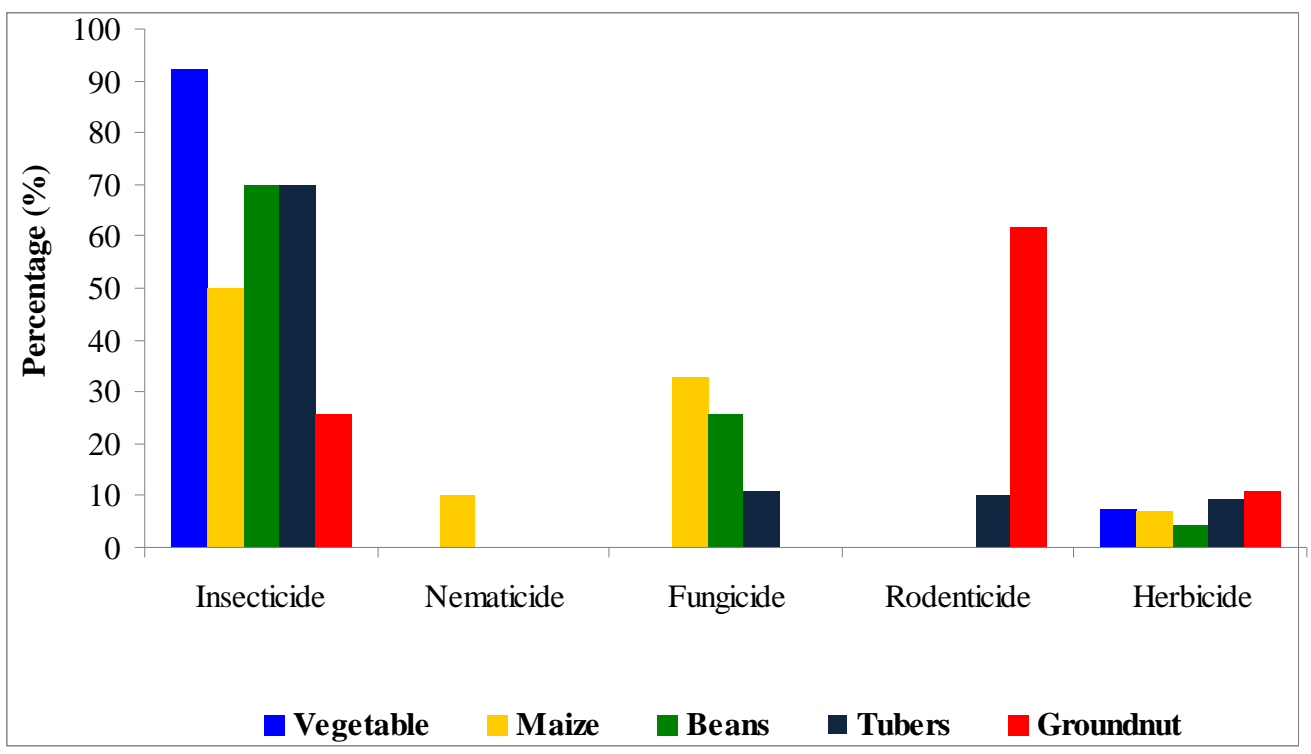

Fig. 3 Pesticides used on different types of crops

Table 2 The use of pesticides in other agricultural activities

\begin{tabular}{lcc}
\hline \multicolumn{1}{c}{ Activity } & Frequency & Percentage (\%) \\
\hline Livestock spraying & 23 & 19.2 \\
Weed control & 97 & 80.8 \\
Malaria vector control & Nil & Nil \\
Cash crop (coffee) spraying & Nil & Nil \\
\hline
\end{tabular}

\section{Discussion}

The current study reveals that $80 \%$ of farm workers are female. This finding suggests that women are highly involved in agriculture. Farming is a viable alternative to waged labor for women who lack access to formal employment due to limited education, training, and other opportunities (Ratta, 1993). Only $59.2 \%$ of the current respondents had completed primary education while none had tertiary education. In a previous study, Abang et al. (2014) reported that only $78 \%$ of Nigerian farmers attended primary school, confirming current findings that majority of farmers are poorly educated and suggesting that level of education impacted awareness and effectiveness pesticide safety information (Elizabeth and Zira, 2009). Similar results were reported in Ecuador, Mozambique and Thailand suggesting that education plays a critical role in handling and management of pesticides among farmers (Jones et al., 2009; Grieshop, 1988; Lorenz et al., 2012). Family size was an important factor in the current study. The current data revealed that $50.8 \%$ of families were middle-sized with 4 to 7 members, which reflected higher amounts of food stored and consumed per household. $60.8 \%$ of the families settled in small farms of 0 to 5 ha, while no families had farms of 15 ha and larger. This means that large scale crop farming is not common in the study area. Taken together, large family size and small farm area may shape how farmers use pesticides. Extensive use of pesticides enables resource-poor farmers to effectively manage their production, since labor and capital are the main limiting factors (Abang et al., 2014). Another important factor shaping pesticide use is the participants' time spent in farming; the current results indicate that majority of the farmers had spent more than 10 years in farming, which may explain 
the high illiteracy rate. Older farmers that are expected to be knowledgeable rely on their past farming experience in their farming practice (Devi, 2009; Jones et al., 2009).

Insects were the most common pests dealt by farmers, followed by fungi and rodents; destruction of crops by nematodes was negligible. Kumar (1991) previously reported that insects were the most dominant and harmful groups of pests. The increase in pest population may be partly attributed to increased uncontrolled use of pesticides by large corporations, leading to increased resistance in pests and untreated fields (Oerke and Dehne, 2004; Cooper and Dobson, 2007). Insecticides made up for the majority of pesticides used in crop pest control compared to nematicides, fungicides, rodenticides and herbicides. These results are in line with reports by Woodruff et al. (1994) reporting that insecticides were the most used pesticide on African crops. Nevertheless, studies reveal that extremely hazardous pesticides continue to be used in low- and/or middle-income countries, such as Peru and Ecuador (Orozco et al., 2009), Philippines (Baurdoux et al., 2004; Del Prado-Lu, 2007), Cambodia (Jensen et al., 2011) and Kenya (Okello and Swinton, 2011). Herbicides are commonly used to control unwanted plants before planting groundnut, tubers, vegetable, maize and beans (EPA, 2011). Several reports indicate that increased access to and use of pesticides can be attributed to the proliferation and accessibility of unlicensed dealer shops that put profits before safety when it comes to pesticides. Webster et al. (1999) state that without the use of pesticides, considerable loss in crop production is inevitable; in contrast, pesticide use significantly increases the yields and the economic margins from crop production.

Apart from using pesticides on vegetable, maize, beans, tubers and groundnut crops, the farmers in Bambili also use large quantities of pesticides for other agricultural activities around their farms. Such activities include livestock spraying and weed control. About nineteen percent (19.2\%) of the respondents reported that they fed their livestock and poultry pesticide-treated crops. These pesticides would be deposited in the adipose tissue of meat and eggs which are the main components of the food chain (Timbrell, 1991). The larger percentage of pesticide was used in weed control, to reduce competition between crops and weeds (80.8\%). In spite of the wide use of pesticides reported herein, Smit et al. (2002) reported an interaction between insecticides, fungicides and the mineral content in water which may affect the efficacy of individual pesticides applied.

A limitation of the current study was the lack of data on the active ingredient content of the different pesticides used by the farmers, since the farmers themselves were unaware of the composition of the pesticides used. Consequently, we were unable to identify toxicity and hazard risks of the pesticides as per WHO standards. The symptoms mentioned by farm workers included headache, wheezing, dizziness and skin problems, which may have occurred from single or combined exposure to pesticides. Moreover, this study was unable to assess duration of exposure to the pesticides, although it is clear that farm workers using pesticides without protective measures were exposed to higher levels which were sufficient to induce acute health symptoms.

\section{Conclusion}

The extensive use of insecticides compared to other pesticides concludes that insects are the most important pest in Tubah Sub-Division. Farmers in Bambili used large quantities of pesticides for livestock spraying and weed control. The farmers showed lack of safety knowledge related to the use of pesticides and the risks of consuming crops containing pesticides on their health and the health of consumers. The farmers were dangerously unaware of the real risks of pesticide use. Although a few of the participants had knowledge of safe use of pesticides, this knowledge failed to translate practically, and most farmers continue to practice poor safety measures. Hence, special educational programs for all farm workers are urgently recommended. Efforts should be directed not only to provide additional knowledge on the risks of pesticide use, but also execution of Personal Protective Measures (PPM) which is necessary to decrease exposure of farm workers to these pesticides regardless of their previous training and experience. 


\section{References}

[1] Abang, A.F., Kouamé, C.M., Abang, M., Hanna, R., \& Fotso, A.K. (2014). Assessing vegetable farmer knowledge of diseases and insect pests of vegetable and management practices under tropical conditions. International Journal of Vegetable Science, 20(3), 240-253.

[2] Baurdoux, M., Snelder, D., \& De Snoo, G. (2004). Pesticides in the Cagayan valley (Philippines): usage, drift patters and exposure of farmers differing in income and market access. Communications in Agricultural and Applied Biological Sciences, 69(4), 765-778.

[3] Ciesielski, S., Loomis, D.P., Mims, S.R., \& Auer, A. (1994). Pesticide exposures, cholinesterase depression, and symptoms among North Carolina migrant farmworkers. American Journal of Public Health, 84(3), 446-451.

[4] Cooper, J., Dobson, H. (2007). The benefits of pesticides to mankind and the environment. Crop Protection, 26, 1337-1348.

[5] Damalas, C.A., Georgiou, E.B., \& Theodorou, M.G. (2006). Pesticide use and safety practices among Greek tobacco farmers: a survey. International Journal of Environment Health Reserch, 16, 339-348.

[6] Dasgupta, S., Meisne, C., \& Huq, M. (2007). A pinch or a pint? Evidence of pesticide overuse in Bangladesh. Journal of Agricultural Economics, 58, 91-114.

[7] Del Prado-Lu, J.L. (2007). Pesticide exposure, risk factors and health problems among cutflower farmers: a cross sectional study. Journal of Occupational Medicine and Toxicology, 2:9 https://doi.org/10.1186/1745-6673-2-9.

[8] Devi, P.I. (2009). Health risk perceptions, awareness and handling behaviour of pesticides by farm workers. Agricultural Economics Research Review, 22(23), 263-268.

[9] Elizabeth, S. \& Zira, D. (2009). Awareness and effectiveness of vegetable technology information packages by vegetable farmers in Adamawa State, Nigeria. Journal of Agriculture Research, 4(2), 6570 .

[10] EPA. (2011). Pesticides industry. sales and usage 2006 and 2007: Market Estimates Archived 201503-18 at the Wayback Machine.

[11] FAO. (2014). Food and Agricultural Organization of the United Nations. [Online], 2014. Pesticides: Balancing Crop Protection and Responsible Use. Plant Production and Protection Division. FAO, Rome, Italyhttp://www.fao.or.jp/fileadmin/ contents/ publications/pub_FS_pesticides_low.pdf.

[12] Focho, D.A., Newu, M.C., Anjah, M.G., Nwana, F.A., \& Ambo, F.B. (2009). Ethnobotanical survey of trees in Fundong, Northwest Region, Cameroon. Journal of Ethnobiology and Ethnomedicine, 5, $17-21$.

[13] Gay, L.R. (1992). Educational Research: Competences for analysis and application (3 ${ }^{\text {rd }}$ ed.) Paris: Merrill.

[14] Grieshop, J.I. (1988). Protective clothing and equipment: Beliefs and behavior of pesticide users in Ecuador. Paper presented at the performance of protective clothing: $2^{\text {nd }}$ symposium, ASTM STP 989, Philadelphia, PA.

[15] Hajjar, M.J. (2012). The persisted organic pesticides pollutant (POPs) in the Middle East Arab countries. International Journal of Agronomy and Plant Production, 3, 11-18.

[16] Hashemi, S.M., \& Damalas, C.A. (2011). Farmers' perceptions of pesticide efficacy: reflections on the importance of pest management practices adoption. Journal of Sustainable Agriculture, 35, 69-85.

[17] House, J.S., Kessler R.C., \&. Herzog, A.R. (1990). Age, socioeconomic status, and health. The Milbank Quarterly, 68, 383-411.

[18] Jensen, H.K., Konradsen, F., Jórs, E., Petersen, J.H., \&. Dalsgaard, A. (2011). Pesticide use and selfreported symptoms of acute pesticide poisoning among aquatic farmers in phnom penh, Cambodia. Journal of Toxicology, Article ID 639814, 8 pages.

[19] Jones, E., Mabota, A., \& Larson, D.W. (2009). Farmers' knowledge of health risks and protective gear associated with pesticide use on cotton in Mozambique. Journal of Developing Areas, 42, 267-282. 
[20] Khan, M., Mahmood, H.Z., \& Damalas, C.A. (2015). Pesticide use and risk perceptions among farmers in the cotton belt of Punjab, Pakistan. Crop Protection, 67, 184-190.

[21] Kumar R. (1991). La lutte contreles insectes ravageurs, la situation de l'agriculture africaine. CTA/Karthala Eds. Wageningen, Paris, $310 \mathrm{p}$

[22] Litchfield, M.H. (2005). Estimates of acute pesticide poisoning in agricultural workers in less developed countries. Toxicology Review, 24, 271-278.

[23] Lorenz, A.N., Prapamontol, T., Narksen, W., Srinual, N., Barr, D.B., \& Riederer, A.M. (2012). Pilot study of pesticide knowledge, attitudes, and practices among pregnant women in Northern Thailand. International Journal of Environmental Research and Public Health, 9, 3365-3383.

[24] Mugenda O.M. \& Mugenda A.G. (1999). Research methods. Quantitative and qualitative approach. pp 15-40 ACTS Press Nairobi, (Kenya).

[25] Oerke, E.C., \& Dehne, H.W. (2004). Safeguarding production-losses in major crops and the role of crop protection. Crop Protection, 23, 275-285.

[26] Okello, J.J., \& Swinton, S. M. (2011). International food safety standards and the use of pesticides in fresh export vegetable production in developing countries: implications for farmer health and the environment: In Pesticides-Formulations, Effects, Fate, M. Stoytcheva, Ed., InTech, Rijeka, Croatia, pp183-198.

[27] Orozco, F.A., Cole, D. C., Forbes, G., Kroschel, J., Wanigaratne, S., \& Arica, D. (2009). Monitoring adherence to the International Code of Conduct: highly hazardous pesticides in Central Andean agriculture and farmers' rights to health. International Journal of Occupational and Environmental Health, 15(3), 255-268.

[28] Pimentel, D. (2005). Environmental and economic cost of the application of pesticides primarily in the United States. Environment Development and Sustainability, 7, 229-252.

[29] Ratta A. (1993). City women farm for food and cash. International Ag-Sieve, 6(2), 1-2.

[30] Smit, Z.K., Indjic, D., Belic, S., \& Miloradov, M. (2002). Effect of water quality on physical properties and biological activity of tank mix insecticide-fungicide spray. In: Paroussi, G., Voyiatzis, D., Paroussis, E., editors. Proceedings of the $2^{\text {nd }}$ Balkan Symposium on Vegetables and Potatoes, (579), 3001

[31] Stadlinger, N., Mmochi, A.J., \& Dobo, S. (2011). Pesticide use among smallholder rice farmers in Tanzania. Environment Development and Sustainability, 13, 641-656.

[32] Stenzel, P.L. (1991). Right-to-know provisions of California's proposition 65: Naivete of the delaney clause revisited. Harvard Environmental Law Review, 15, 493-528.

[33] Tilman, D., Cassman, K.G., Matson, P.A., Naylor, R., \& Polasky, S. (2002). Agricultural sustainability and intensive production practices. Nature, 418, 671-677.

[34] Timbrell J.A. (1991). Principals of biochemical toxicology. Published by Taylor Francis Washington DC, (USA), 5-8.

[35] Verger, P.J.P., \& Boobis, A.R. (2013). Reevaluate pesticides for food security and safety. Science, $341,717-718$.

[36] Webster J.P.G., Bowles R.G., \& Williams N.T. (1999). Estimating the economic benefits of alternative pesticide usage scenarios: wheat production in the United Kingdom. Crop Protection, 18, 83-89.

[37] Williams, D.R. (1990). Socioeconomic differentials in health: A review and redirection. Social Psychology Quarterly, 53, 81-99.

[38] Wilson, C., \& Tisdell, C. (2001). Why farmers continue to use pesticides despite environmental, health and sustainability costs? Ecological Economics, 39, 449-462.

[39] Woodruff, T.J., Kyle, A.D., \& Bois, F.Y. (1994). Evaluating health risks from occupational exposure to pesticides and the regulatory response. Environmental Health Perspectives, 102(12), 1088-1096. 